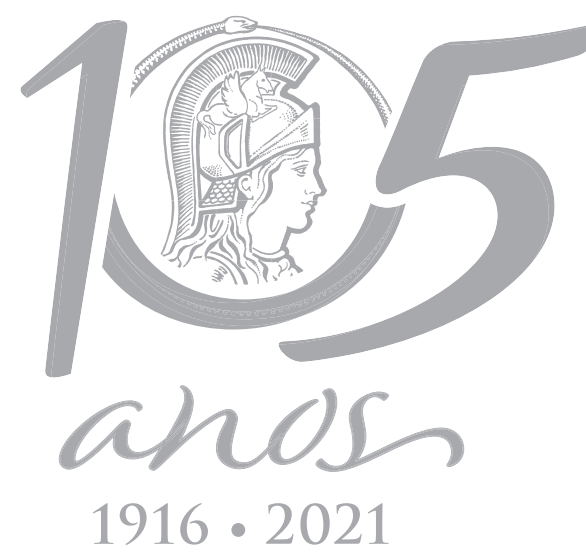

\title{
Leptin negatively regulates thyroid function of Wistar rats
}

\author{
FABIO HECHT, JULIANA CAZARIN, CAMILA L. ROSSETTI, DORIS ROSENTHAL, \\ RENATA L. ARAUJO \& DENISE P. CARVALHO
}

\begin{abstract}
Leptin plays a major role in the regulation of energy intake and energy expenditure, triggering effects on several tissues, such as the hypothalamic-pituitarythyroid axis. The reported effects of leptin on the thyroid are controversial, being mainly explored during energy imbalance. Therefore, the aim of this study was to evaluate the effects of leptin on thyroid function of rats fed ad libitum distinguishing direct leptin responses from those mediated by leptin-dependent suppression of food intake by comparing leptin-treated (L) with pair-fed (PF) animals. Leptin administration resulted in a decrease of $10 \%$ in food intake. Reduced mass gain was observed on both $L$ and PF groups. Leptin administration decreased serum corticosterone, which did not occur in the PF group. TSH levels were reduced in PF group, but not in the L group. Both L and PF animals presented reduced iodide uptake and type 1 deiodinase (D1) activity in the thyroid gland. A decrease of D1 activity was also found in the $\mathrm{PCCl} 3$ rat thyroid cell lineage treated with leptin. Taken together the data suggest that leptin exerts paradoxical effects: a stimulatory effect on the hypothalamic-pituitary-thyroid axis by increasing TSH levels while directly inhibiting thyrocyte function in a TSH-independent fashion.
\end{abstract}

Key words: deiodinase, hypothalamus-pituitary-thyroid axis, iodide uptake, leptin, thyroid.

\section{INTRODUCTION}

The homeostatic mechanisms that regulate body mass and food intake are fairly complex and may involve numerous hormones, neurotransmitters and peptides that modulate responses in both the central nervous system and in peripheral tissues. Leptin, a $16 \mathrm{kDa}$ peptide hormone secreted mainly by adipocytes, plays a major role in this issue, regulating both energy intake and energy expenditure (Ahima et al. 1996, Frederich et al. 1995, Pelleymounter et al. 1995, Zhang et al. 1994). This hormone acts predominantly on hypothalamic nuclei and, also, in neuronal circuits of the brainstem that regulate feeding behavior and energy balance
(Campfield et al. 1995, Elmquist et al. 1999). When serum leptin levels are high, such as after a meal or when the adipose tissue mass accumulates, excitatory signals to hypothalamic neurons that express $\alpha$-MSH/CART predominate, as well as inhibitory signals and connections to neurons that express NPY/AgRP. As a result, there is a reduction of orexin and melaninconcentrating hormone $(\mathrm{MCH})$ expression in the lateral nucleus of the hypothalamus, which altogether lead to diminished food intake (Horvath et al. 1999, Schwartz et al. 1996, 2000). It is well established that, in rodents and humans, mutations in the leptin or leptin receptor genes cause hyperphagia, morbid obesity, metabolic and neuroendocrine abnormalities, including 
hyperinsulinemia, hypercortisolism and hypothalamic hypogonadism (Coleman 1978, Halaas et al. 1995).

Central regulation by leptin triggers complex processes that lead to indirect effects on peripheral tissues. Such leptin effects include the activation of the hypothalamic-pituitarythyroid axis. Nillni et al. (2000) demonstrated that leptin exerts important central regulation, such as the increase in proTRH gene expression and TRH release in the paraventricular nucleus of the hypothalamus (Nillni et al. 2000). Moreover, proTRH expression can be indirectly stimulated by leptin, since $\alpha-M S H$ (positively modulated by leptin) stimulates the secretion of TRH, whereas AgRP (negatively modulated by leptin) inhibits it (Fekete et al. 2000, 2002, Ghamari-Langroudi et al. 2010, Kim et al. 2000). Besides this action on the hypophysiotropic TRH neurons, the presence of the leptin receptor in pituitary and in thyroid gland suggests that leptin may also exert direct actions on the secretion of TSH and thyroid function (Jin et al. 2000, Nowak et al. 2002). In humans, a strong positive correlation between the circadian cycles of leptin and TSH has been demonstrated, and the circadian cycle of TSH is drastically altered in individuals with leptin production deficiency (Mantzoros et al. 2001). In rodents fed ad libitum, an acute treatment with leptin was able to positively modulate TSH secretion in vivo and, paradoxically, to regulate it negatively in vitro (Ortiga-Carvalho et al. 2002).

Similarly, reports of leptin actions on the thyroid gland are controversial. Iodide is essential for thyroid hormones biosynthesis and the sodium-iodide symporter (NIS) ensures the active transport of iodide into the thyrocytes. It has already been shown that leptin administration had inhibitory effects over thyroid iodide uptake in FRTL5 cells and in thyroid explants (Isozaki et al. 2004, de Oliveira et al. 2007). However, in vivo, treatment of rats with leptin for 6 days stimulated iodide uptake by the thyroid, whereas the acute treatment (1 day) did not cause modifications in this parameter (de Oliveira et al. 2007). It has also been demonstrated that leptin has a stimulatory effect on the thyroid type I deiodinase (D1) (Lisboa et al. 2003). These data suggest that leptin should be a modulator of thyroid function, independently of its central regulation mediated by TRH and TSH.

In addition to its role as an anorexigenic hormone, leptin mediates the adaptation to fasting. This response is mediated by a reduction in insulin and a rise in counterregulatory hormones, i.e., glucagon, epinephrine, and glucocorticoids (Schwartz et al. 1997). Previous studies suggest that negative energy balance leads to suppression of the hypothalamuspituitary-thyroid axis, while positive energy balance stimulates it (Araujo et al. 2009, 2010, Connors et al. 1985, Rondeel et al. 1992). In situations of energy deprivation, when serum levels of leptin are low, there is inhibition of TRH release, a fact attributed to suppression of the proTRH gene and its processing into mature TRH (Légrádi et al. 1997, Nillni et al. 2000, Sanchez et al. 2004). TRH inhibition decreases TSH secretion, which leads to a reduction in thyroid function (Blake et al. 1991, Rondeel et al. 1992) In such a negative energy status, leptin administration was able to stimulate proTRH expression and to reestablish serum levels of thyroid hormones (Sanchez et al. 2004).

It is well known thatTSH is the most important stimulator of thyroid hormone biosynthesis and, thus, stimulates iodide uptake and thyroid type 1 deiodinase expression. Replacement of leptin in rats that are food restricted, and therefore have low serum leptin, restored serum TSH levels but inhibited iodide uptake, this reinforces the idea of a direct negative effect of leptin on NIS regulation (Araujo et al. 2009). 
The investigation concerning the action of this hormone under different physiological conditions remain poorly understood. It is important to note that the vast majority of studies previously published in the field have used models of energy imbalance (fasting, food restriction or obesity), while the effect of leptin on the hypothalamic-pituitary-thyroid axis under dynamic equilibrium conditions is not well known. Therefore, the main objective of this study was to investigate the direct influence of leptin on thyroid function in vitro and in vivo in rats fed ad libitum, differentiating direct leptinresponses from those secondary to suppression of food intake that might be secondary to energy imbalance rather than to leptin actions.

\section{MATERIALS AND METHODS}

\section{Animals}

Adult male Wistar rats weighing around $250 \mathrm{~g}$ were housed at controlled temperature $\left(24 \pm 2^{\circ} \mathrm{C}\right)$ with daily exposure to a $12 \mathrm{~h}$ light:12 h darkness cycle (lights on at 07:00 pm), and free access to tap water and standard rat chow. Animal care and procedures were conducted in accordance with the Guide for the Care and Use of Laboratory Animals published by the US National Institutes of Health (NIH Publication No.85-23, revised 1996) and the study was approved by the Institutional Animal Welfare Committee (CEUA - IBCCF 077). All the animals were individually housed for a 2-week acclimation period and baseline control food intake was assessed.

\section{Leptin treatment}

Rats were randomly assigned to three groups: Control (C), Leptin (L) and Pair-Fed (PF). The treatment protocol entailed 10 consecutive days with twice daily (08:00 am and 05:00 pm) subcutaneous injections of $10 \mu \mathrm{g} / 100 \mathrm{~g}$ of body weight of recombinant rat leptin (National
Institute of Diabetes \& Digestive \& Kidney Diseases - NIDDK) reconstituted in PBS buffer ( $\mathrm{pH}$ 7.4) for $\mathrm{L}$ group. The leptin dose of each injection was daily adjusted for body weight. Control and Pair-Fed groups received PBS buffer ( $\mathrm{pH}$ 7.4) injections at the same hours.

\section{Pair-feeding}

Because leptin administration results in reduced food intake (Mistry et al. 1997), a Pair-Fed (PF) group was created to rule out the effects of food restriction per se on the thyroid function, since we are specifically interested in the possible direct effects of leptin on thyroid. The PF group was fed with the average food intake of the leptin-treated group corrected for body mass. Example: If $L$ group's average food intake on day 2 were $9.0 \mathrm{~g} / 100 \mathrm{~g}$ of body weight, a pair-fed animal weighing $300 \mathrm{~g}$ would receive $27.0 \mathrm{~g}$ of chow on day 3. The values of food intake related to animal weight were corrected daily.

\section{Blood and thyroid gland collection}

After the experimental period (10 days), all animals were euthanized by decapitation and blood was collected from the trunk. The animals were euthanized $3 \mathrm{~h}$ after the last leptin or vehicle administration. Serum was obtained after centrifugation of blood at 1,500 $\times \mathrm{g}$ for 20 minutes at room temperature and stored at $-20^{\circ} \mathrm{C}$ until specific radioimmunoassay (TSH, T3, T4, corticosterone and leptin) was performed. The thyroid gland was used for in vivo iodide uptake measurement (as described below) or stored at $-70^{\circ} \mathrm{C}$ until processing for type 1 deiodinase enzyme (D1) activity analysis.

\section{Cell culture}

The PCCl3 rat thyroid cell line (Fusco et al. 1987) was maintained in Coon's modified Ham's F-12 medium supplemented with $5 \%$ fetal bovine serum, and a six-hormone mixture containing 5 
$\mu \mathrm{g} / \mathrm{mL}$ transferrin, $10 \mathrm{nM}$ hydrocortisone, $10 \mathrm{ng} /$ $\mathrm{mL}$ somatostatin, and $10 \mathrm{ng} / \mathrm{mL}$ glycyl-L-histidylL-lysine acetate, $1 \mathrm{mU} / \mathrm{mL}$ TSH, $10 \mu \mathrm{g} / \mathrm{ml}$ insulin (Souza et al. 2010). The effect of $100 \mathrm{ng} / \mathrm{mL}$ of recombinant leptin on type 1 deiodinase activity was studied using near-confluent cells in the absence of TSH and insulin, in the presence of $0.2 \%$ fetal bovine serum (starving medium) for 24 hours. TSH, insulin, transferrin, hydrocortisone, somatostatin, glycyl-L-histidyl-L-lysine acetate and dithiothreitol were purchased from SigmaAldrich Corporation (St. Louis, MO, USA). F-12 medium was obtained from HiMedia (Mumbai, India) and Fetal Bovine Serum (FBS) from ThermoFischer (Waltham, MA, USA).

\section{Serum TSH, leptin, corticosterone and total T3 and T4}

Serum TSH levels were evaluated by a specific RIA obtained from the National Institute of Diabetes, Digestive and Kidney Diseases (NIDDK, Bethesda, MD, USA). Serum total T3 and T4 concentrations were measured using commercial RIA kits (T3: DSL - 3100 Active; T4: DSL - 3200 Active; DSL, TX, USA), based on the presence of specific antibodies adhered to the internal surface of propylene tubes. Rat hormone-stripped serum was used for standard curves of TSH. Serum leptin concentrations were measured using a specific RIA for rat leptin obtained from the Linco Research Company (St. Charles, MO, USA). Serum corticosterone concentrations were measured using a specific RIA (ImmuChemTM ${ }^{125}$ I) obtained from MP Biomedicals, LCC (Orangeburg, NY, USA). All the procedures were carried out following the manufacturer recommendations.

\section{In vivo rat thyroid iodide uptake}

In vivo iodide uptake by the thyroid gland was performed as previously described (Ferreira et al. 2005). The animals received [ ${ }^{125}$ ] $\mathrm{Nal}(3,700$ $\mathrm{Bq} / 300,000$ CPM i.p., Amersham) 15 min prior to decapitation. Thyroids were removed and weighed, and their radioactivity was measured using a gamma counter. The iodide uptake by the thyroid gland was expressed as percentage of total ${ }^{125}$ I injected per mg of thyroid tissue.

\section{Rat thyroid type 1 deiodinase assay}

Type 1 iodothyronine deiodinase activity was evaluated by measuring the release of ${ }^{125} \mathrm{I}$ - from $\left[{ }^{125} \mathrm{I}\right]$-rT3 as previously described by our group (Araujo et al. 2008) and based on Berry et al. (1991). Fifteen milligrams of thyroid tissue were homogenized in $1 \mathrm{~mL}$ of $0.1 \mathrm{M}$ sodium phosphate buffer containing $1 \mathrm{mM}$ EDTA, $0.25 \mathrm{M}$ sucrose, and $10 \mathrm{mM}$ dithiothreitol ( $\mathrm{pH}$ 6.9). Protein concentration was measured by the Bradford method (Bradford 1976). Thyroid homogenates containing $15 \mu \mathrm{g}$ of protein were incubated for 1 hour at $37^{\circ} \mathrm{C}$ with $1 \mu \mathrm{M} \mathrm{rT3}$ (Sigma, St. Louis, MO, USA), containing $\left[{ }^{125}\right]$-rT3 (Perkin-Elmer Life Sciences, Boston, MA, USA; previously purified using sephadex LH-2), in a final volume of 300 $\mu \mathrm{L}$ of homogenization buffer. Negative control incubations were performed in the absence of sample. The reaction was stopped at $4^{\circ} \mathrm{C}$ by the addition of $200 \mu \mathrm{L}$ fetal bovine serum (Cultilab, Campinas, Brazil) and $100 \mu \mathrm{L}$ trichloroacetic acid $(50 \%, v / v)$. The samples were centrifuged at $8,000 \times \mathrm{g}$ for $3 \mathrm{~min}$, and $360 \mu \mathrm{L}$ of the supernatant was collected for measurement of ${ }^{125}$ I released from deiodination reaction using an automated gamma counter. The specific enzyme activity was expressed as picomoles of product per minute per milligram of protein (pmoles $\mathrm{min}^{-1} \mathrm{mg}^{-1}$ ).

\section{Statistical analysis}

Results are expressed as mean \pm S.E.M., and were analyzed by one-way ANOVA, followed by Bonferroni's multiple comparison tests. In vitro results were analyzed by two-tailed t-test. Serum TSH concentration was analyzed by Kruskal-Wallis followed by the Dunn's multiple 
comparison tests. Results were analyzed with GraphPad Prism (version 8, GraphPad Software, Inc., San Diego, CA, USA). Differences were considered significant when $\mathrm{P}<0.05$.

\section{RESULTS}

\section{Leptin effects on body mass, food intake and} fat pads mass

The administration of $10 \mu \mathrm{g} / 100 \mathrm{~g}$ b.w. of leptin twice a day for 10 days promoted a statistically significant reduction in body mass gain in relation to the control animals. Remarkably, the vehicle-treated pair-fed animals had an even stronger reduction in mass gain (Figure 1c). Leptin administration diminished food intake by $10 \%$ (Figure 1a-b) and this reduction was used to calculate the mass of food offered for the pair-fed animals. Although body mass gain was altered in both $L$ and PF animals, the absolute and relative masses of epididymal and retroperitoneal fat deposits were not affected (Figure 1d-e).

\section{Serum hormone concentrations are influenced by leptin treatment}

After the 10-day experiment, serum was collected for hormonal analysis. Hyperleptinemia was a

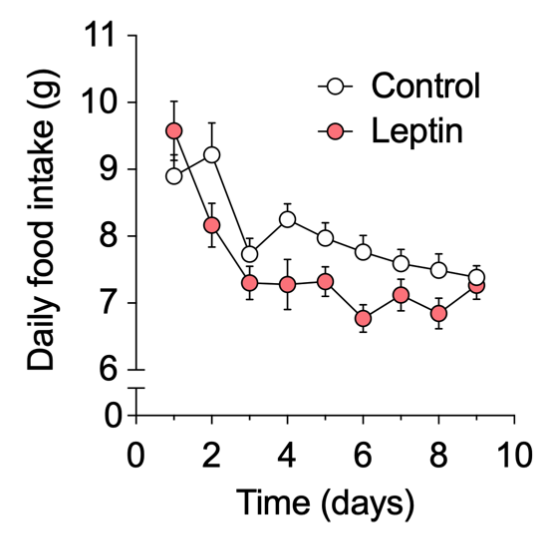

d

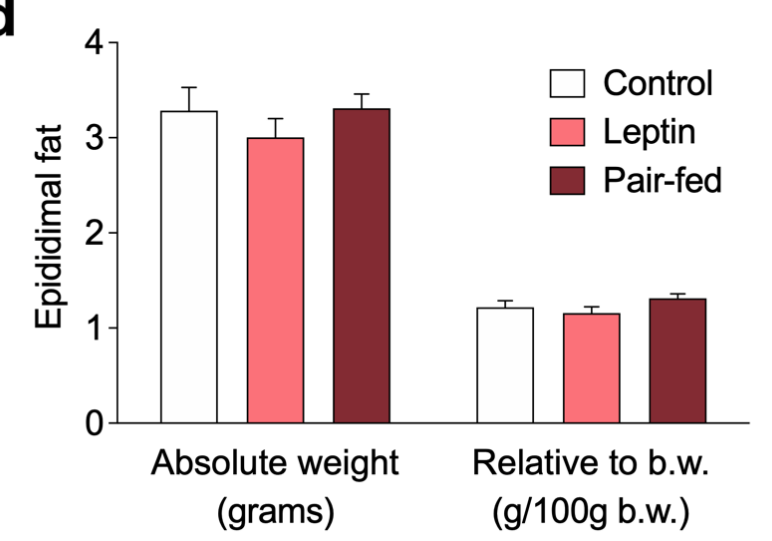

b

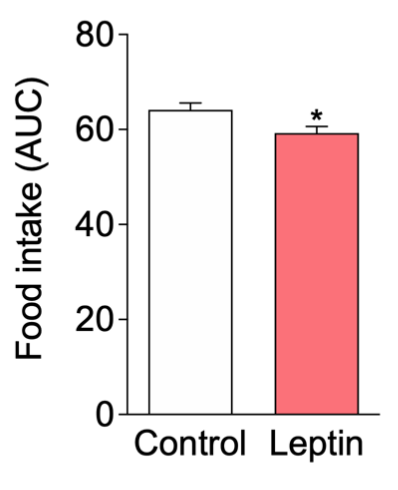

C

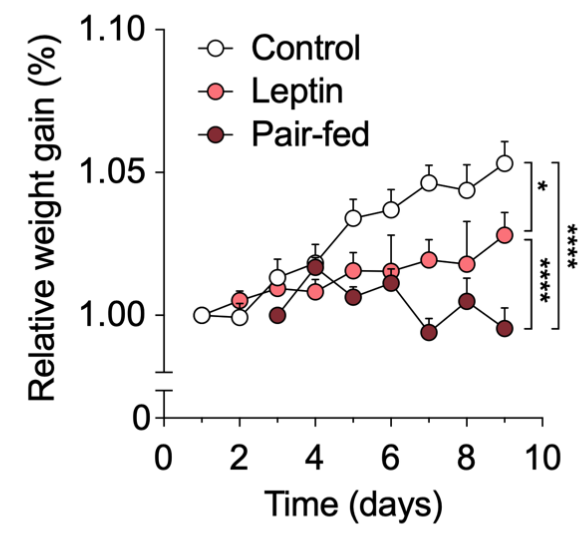

e

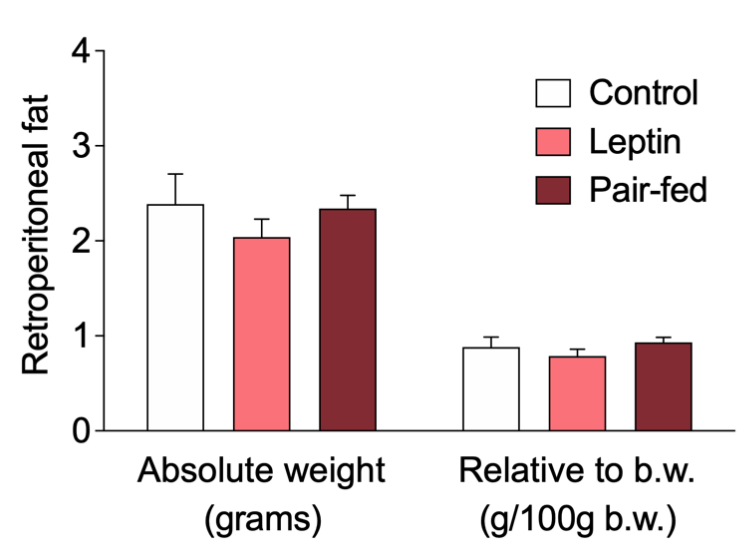

Figure 1. Leptin effects on body mass, food intake, and fat deposits mass. a. Absolute food consumption of control and leptin groups. The pair-fed group was fed with the exact amount of chow consumed by the leptin group in the earlier day. b. Area under the curve of food consumption. c. Mean body mass gain of control, leptin, and pair-fed animals relative to the first day of treatment of each group. d-e. Absolute and relative values of epididymal (d) and retroperitoneal (d) fat deposits. $N=15-20$ animals per group. ${ }^{*} P<0.05,{ }^{* * * *} P<0.0001$. 
confirmed by radioimmunoassay (Figure 2a). Corticosterone was suppressed in the leptintreated group but not in the pair-fed group (Figure 2b). Indeed, a statistically significative negative correlation was observed between serum leptin and corticosterone (Figure 2c). The serum concentrations of total T3 and T4 were not altered by the treatments (Figure $2 \mathrm{~d}-\mathrm{e}$ ), even though serum TSH was diminished in the pairfed group (Figure 2f).

\section{Leptin negatively impacts thyroid function}

In order to investigate thyroid function, the activity of two key steps in the thyroid hormone secretion that are stimulated by TSH, the iodide uptake by the sodium-iodide symporter (NIS) and type 1 deiodinase (D1) activity, were evaluated (Carvalho \& Dupuy 2017). In rats, thyroid D1 activity was suppressed by both leptin treatment and pair-feeding (Figure 3a). Leptin also inhibited D1 activity in PCCl3 cells, an immortalized rat thyroid cell lineage (Figure 3b). The iodide uptake by the thyroid gland was also impaired in both Leptin and Pair-fed (Figure 4).

\section{DISCUSSION}

The direct effects of leptin on the thyroid gland remain controversial, probably as a result of the different methodologies used for each study, such as different leptin doses (Cabanelas et al. 2007), routes of administration (Deem et al. 2018), treatment duration (Lisboa et al. 2003, de Oliveira et al. 2007), and mainly, the energy status of the subjects (fed, fasted, food restricted or obese) (Araujo et al. 2009, 2010, a
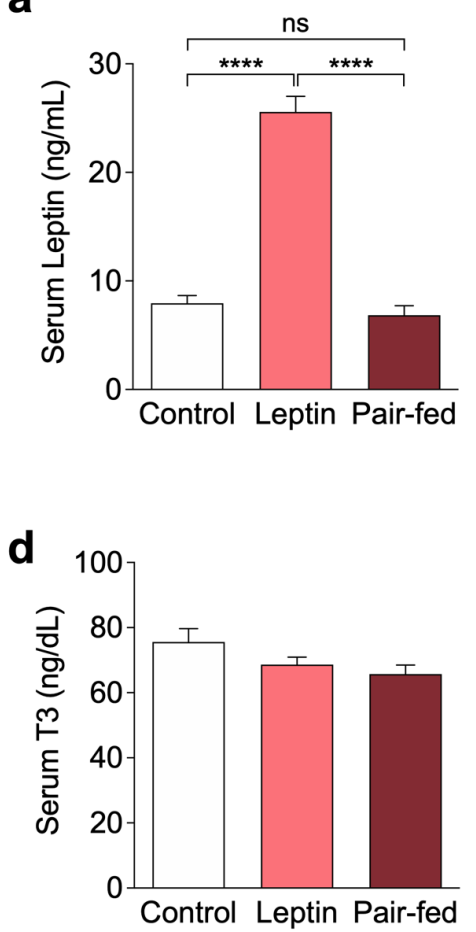

b

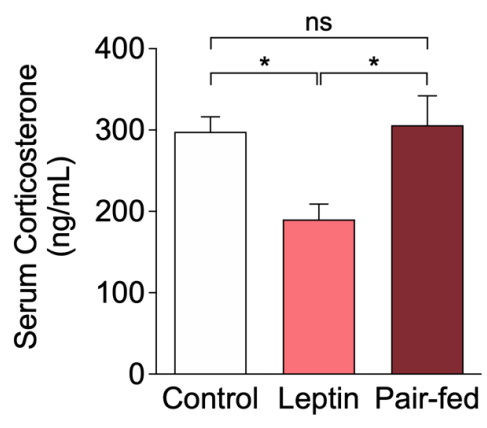

e

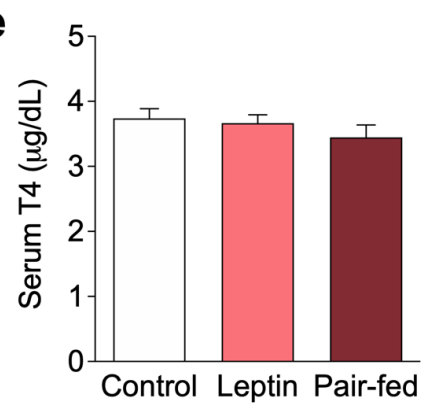

C
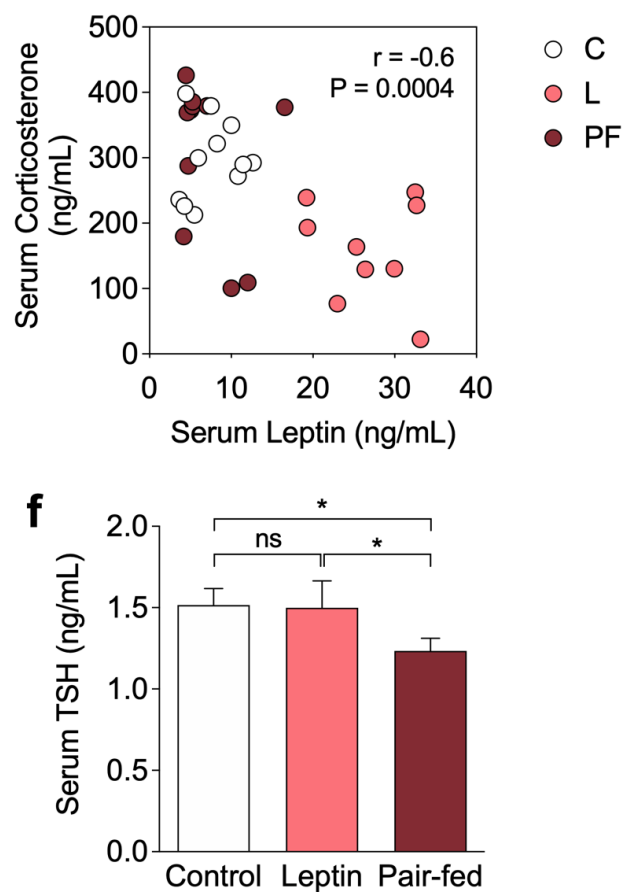

Figure 2. Serum hormone concentrations are influenced by leptin treatment. a-f. Serum hormone concentrations of leptin, corticosterone, total T3, total T4, and TSH were measured by radioimmunoassay after 10 days of leptin treatment or pair-feeding. c. Pearson's correlation between serum leptin and serum corticosterone of animals from the three groups. $N=8-10$ animals per group. ${ }^{*} P<0.05$, ${ }^{* * *} P<0.0001$, ns: non-significant. 
Lisboa et al. 2015, Perello et al. 2010). Indeed, most of our current understanding about the role of leptin on the thyroid gland comes from animal models with energy imbalance (Ahima et al. 1996, Araujo et al. 2009, Blake et al. 1991, Légrádi et al. 1997, Rondeel et al. 1992) with very little information about its role in animals fed ad libitum. Thus, we designed a 10-days protocol in which male adult rats with free access to standard chow were injected twice a day, and constantly monitored for body mass gain and food intake. All experiments were conducted with a pair-fed group, allowing us to distinguish the direct effects of leptin from those secondary to the suppression of food intake.

Our first observation was a very robust impact of leptin on body mass gain (Figure 1c). It is well established that leptin, besides its central effects on appetite, activates major metabolic pathways related to energy expenditure and may, hence, affect body mass (Döring et al. 1998, Hwa et al. 1997, Scarpace et al. 1997, Yadav et al. 2009). We also observed in the pair-fed group, composed of animals that ate as much as the leptin-treated animals - but received no leptin - an even stronger impact on body mass loss. A major difference between these two groups is the fact that even though both are energy deprived, the leptin group is satiated, while the pair-fed group may be under mild starvation stress. Consistent with data from the literature (Araujo et al. 2009), the daily administration of $0.2 \mu \mathrm{g} / \mathrm{g}$ b.w. was able to suppress food intake by 10\% (Figure 1a-b). Other studies that evaluated the effect of leptin administration on food intake of animals fed ad libitum with doses ranging from 0.5 to $10 \mu \mathrm{g} / \mathrm{g}$ b.w. per day detected an inhibition ranging from 33 to $50 \%$, disclosing a dose-dependent inhibitory effect of leptin on food intake (Barzilai et al. 1997, Cettour-Rose et al. 2002, Steinberg et al. 2002). Although we did observe a modulation of both body mass and food intake, fat deposits were not significantly altered by the 10 days treatment in either the leptin or the pair-fed group (Figure 1d-e).

Hyperleptinemia was confirmed in the leptin group and was not observed in the pair-fed group (Figure $2 \mathrm{a}$ ). The levels of corticosterone were diminished in the leptin group but not in the pair-fed, suggesting a direct role of leptin on the adrenal and/or hypothalamus-pituitaryadrenal axis, and not an effect secondary to food restriction (Figure $2 b$ ). An inverse relationship between leptin and corticosterone was first observed by Ahima (1996) more than 20 years ago, in a seminal paper, which suggested that leptin could regulate the pattern of diurnal corticosterone secretion in mice. It has been

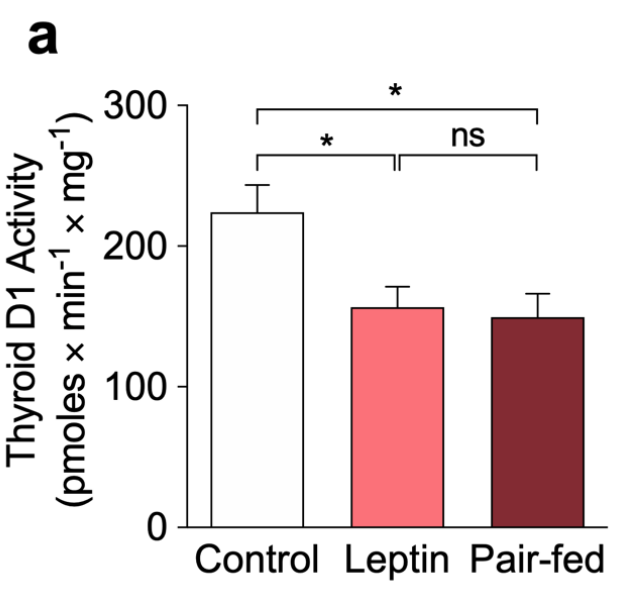

b

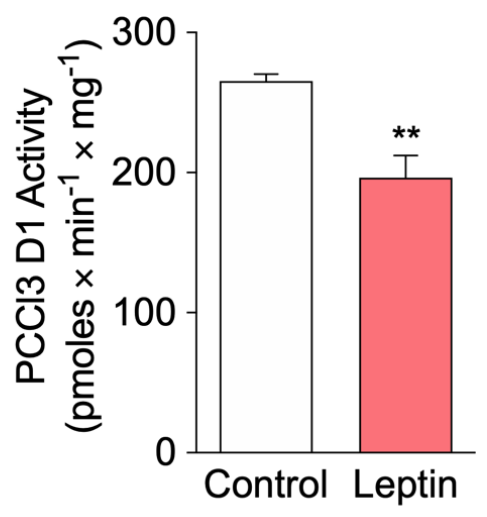

Figure 3. Ex vivo and in vitro thyroid type 1 deiodinase activities are suppressed by leptin. a. Ex vivo D1 activity in the thyroid gland of male Wistar rats. $\mathrm{N}=$ 9-12 animals per group. b. In vitro D1 activity in $\mathrm{PCCl} 3$ cell line. $\mathbf{N}=\mathbf{3}$ independent experiments. ${ }^{*} P<0.05,{ }^{* *} P<0.01$, ns: non-significant. 
shown that leptin administration could prevent the fast-induced rise in corticosterone in rats (Ahima et al. 1996) and even suppress corticosterone levels in both fed and 48h-fasted rats (Coppola et al. 2005). Moreover, we detected a statistically significant negative correlation between serum leptin and corticosterone levels (Figure 2c). Of note, the leptin-induced suppression of corticosterone, an orexigenic hormone, might be a synergistic mechanism of leptin's central effects on the arcuate nucleus in promoting anorexia.

Serum T3 and T4 levels are typically decreased in response to long-term energy deprivation, as an homeostatic mechanism to save energy by preventing catabolic pathways and thermogenesis (Iwen et al. 2018). This decrease is secondary to a suppression of the hypothalamus-pituitary-thyroid (HPT) axis that is triggered by multiple circulating factors, including low levels of leptin. A study from our group revealed that animals submitted to 25 days

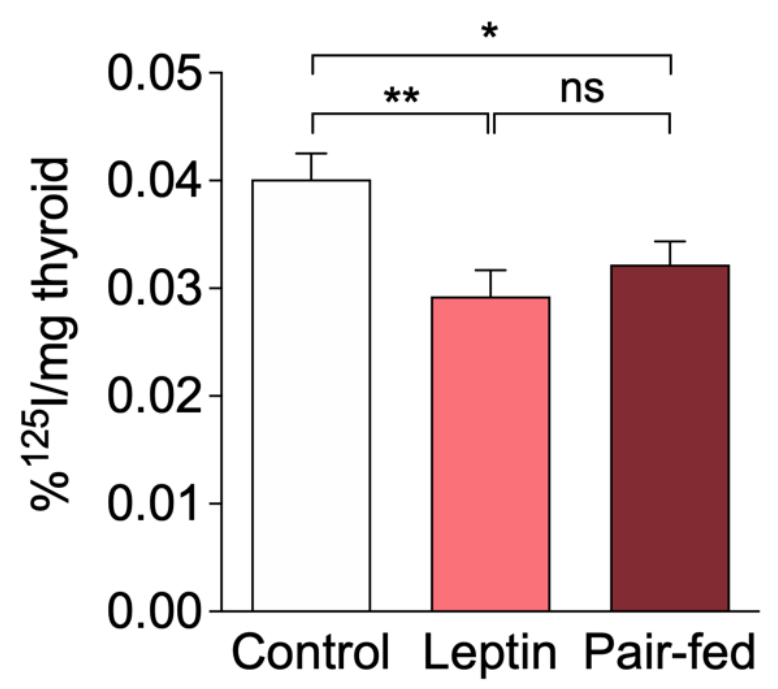

Figure 4. Leptin and pair-feeding impair in-vivo iodide uptake by the thyroid gland. Radioactivity was measured in the thyroid of Wistar rats $15 \mathrm{~min}$ after [ $\left.{ }^{125} \mathrm{I}\right] \mathrm{Nal}(3,700 \mathrm{~Bq} / 300,000 \mathrm{CPM})$ i.p. injection. $\mathrm{N}=6-9$ animals per group. ${ }^{*} P<0.05,{ }^{*} P<0.01$, ns: non-significant. of a $40 \%$ food restriction presents decreased levels of leptin, T3, T4, and TSH. However, when leptin was administered during the last 10 days of the 25-day restriction protocol, all suppressed hormones were at least partially restored (Araujo et al. 2009). Still, it remained unclear whether the rescue of thyroid hormones levels was secondary to an attenuation in HPT axis suppression or a direct effect of leptin on the thyroid gland. Our results indicate that neither leptin treatment nor the $10 \%$ restriction to which pair-fed animals were submitted provoked a decrease in serum thyroid hormones (Figure 2de), corroborating previous data that compared various degrees of food restriction and revealed that only restrictions greater than $30 \%$ are capable of promoting low serum T3 and T4 (Laws et al. 2007).

Additionally, serum concentrations of thyroid stimulating hormone (TSH) can be ambiguously modulated by leptin. Ortiga-Carvalho (2002) showed that the incubation of pituitary explants with nanomolar concentrations of leptin in vitro inhibited TSH secretion. However, this direct effect observed under non-physiological conditions seems to be surpassed in vivo by the positive effect of leptin on TRH, since the treatment of ad libitum fed rats with leptin leads to an increase in serum TSH (Ortiga-Carvalho et al. 2002). Our results show that food restriction of about 10\% (pair-fed group) led to decreased serum TSH levels, while leptin treatment that induces the same level of food restriction, prevented TSH inhibition, suggesting a direct stimulatory effect of leptin on the pituitary (Figure 2f). One possible interpretation of this phenomena is that the mild food restriction to which leptin and pair-fed groups are submitted are inducing a decrease in TSH levels. However, due to the well stablished stimulatory effect of leptin on TRH, and consequently, TSH secretion, the leptin group has its TSH levels restored, while 
pair-fed animals do not, which corroborates previous data showing that leptin can restore TSH levels in rats and humans under negative energy balance (Araujo et al. 2009, Chan et al. 2003, Sanchez et al. 2004). Glucocorticoids are well-known regulators of HPT axis, reducing hypophyseal TSH secretion in both humans and rodent models (Annunziato et al. 1977, Pamenter \& Hedge 1980, Samuels 1994, 2000, Wilber \& Utiger 1969). It is important to note that the leptin-induced decrease of corticosterone serum levels found in our model, might be an additional mechanism involved in the TSH restoration in the leptin treated group (Figure 2b).

Ex vivo, in vivo, and in vitro models were used to assess the activity of key enzymes of thyroid physiology. Previous studies have shown that the thyroid D1 activity is diminished during food restriction, and that leptin reposition to food restricted animals does not restore D1 activity, although serum TSH was reestablished (Araujo et al. 2009). Another report revealed that the acute administration of a single dose of leptin to fed rats stimulates thyroid D1 activity (Lisboa et al. 2003), which is coherent with the acute stimulation of TRH and TSH secretions by leptin, since D1 is modulated by TSH (Araujo et al. 2009, Chan et al. 2003, Légrádi et al. 1997, Ortiga-Carvalho et al. 2002). However, the effect of a longer period of leptin treatment to fed animals remained unclear. We show herein that both leptin and pair-fed rats have diminished thyroid D1 activity compared to controls (Figure 3a). Hence, this result indicated the existence of a direct inhibitory effect of leptin on the thyroid D1, apart from the consequence of food restriction alone, because TSH, a thyroid D1 stimulator, was restored by leptin, but remained low in the pair-fed group. Using a cellular model of rat thyroid cells (PCCl3), we found that leptin can in fact directly suppress thyroid D1 activity
(Figure 3b). Thus, it is possible to speculate that leptin-treated rats have decreased D1 activity due to a direct inhibition while pair-fed rats have decreased D1 activity due to lower serum TSH levels.

The role of leptin on iodide uptake by the thyroid, a crucial mechanism for thyroid function, is also a complex issue with divergent reports presented in the literature. Isozaki et al. (2004) showed that leptin treatment of FRTL-5 rat thyroid cell lineage downregulates NIS mRNA and iodide uptake (Isozaki et al. 2004). Conversely, another group showed that the treatment of fed rats with leptin for 6 days stimulates iodide uptake in vivo (de Oliveira et al. 2007). However, when the thyroid glands from these animals were excised and incubated with iodide ex vivo, they had a lower capacity to uptake iodide (de Oliveira et al. 2007). Previous studies from our team also revealed that the treatment of food-restricted rats with leptin resulted in iodide uptake inhibition (Araujo et al. 2009). In the present work, both leptin-treated and pair-fed animals had diminished thyroid iodide uptake compared to controls (Figure 4). It thus seems that, similarly to what happens with D1 activity, while leptin-treated animals are likely to have lower iodide uptake due to a direct effect of leptin, the pair-fed group might have lower iodide uptake due to lower serum TSH.

Considering that both leptin and thyroid hormones play a fundamental role in the regulation of energy expenditure and food intake, it is very important to understand how these hormones interact in order to better understand the mechanisms involved in body mass regulation. In the present study, we investigated the effects of leptin on thyroid D1 activity and iodide uptake that can be directly attributed to hyperleptinemia and dissociate it from those resulting from decreased food intake induced by leptin. It was found that leptin treatment causes 
a decrease in iodine uptake and thyroid D1 activity, demonstrating a direct inhibitory effect of leptin on these thyroid function parameters, since serum TSH is unchanged in these animals. Despite this, serum levels of $\mathrm{TH}$ remained unchanged, showing that 10 days of $10 \%$ food restriction is unable to significantly change serum thyroid hormone levels. Therefore, this work contributes to a better understanding of the fundamental role that leptin exerts on hypothalamic-pituitary-thyroid axis and, more specifically, on key-mechanisms related to thyroid gland function (model in Figure 5).

\section{Acknowledgments}

We are deeply grateful for the valuable contributions of Professor Tamar Frankenfeld (in memorian). The authors also thank Advaldo Nunes Bezerra and Wagner Nunes Bezerra for the technical assistance. This work

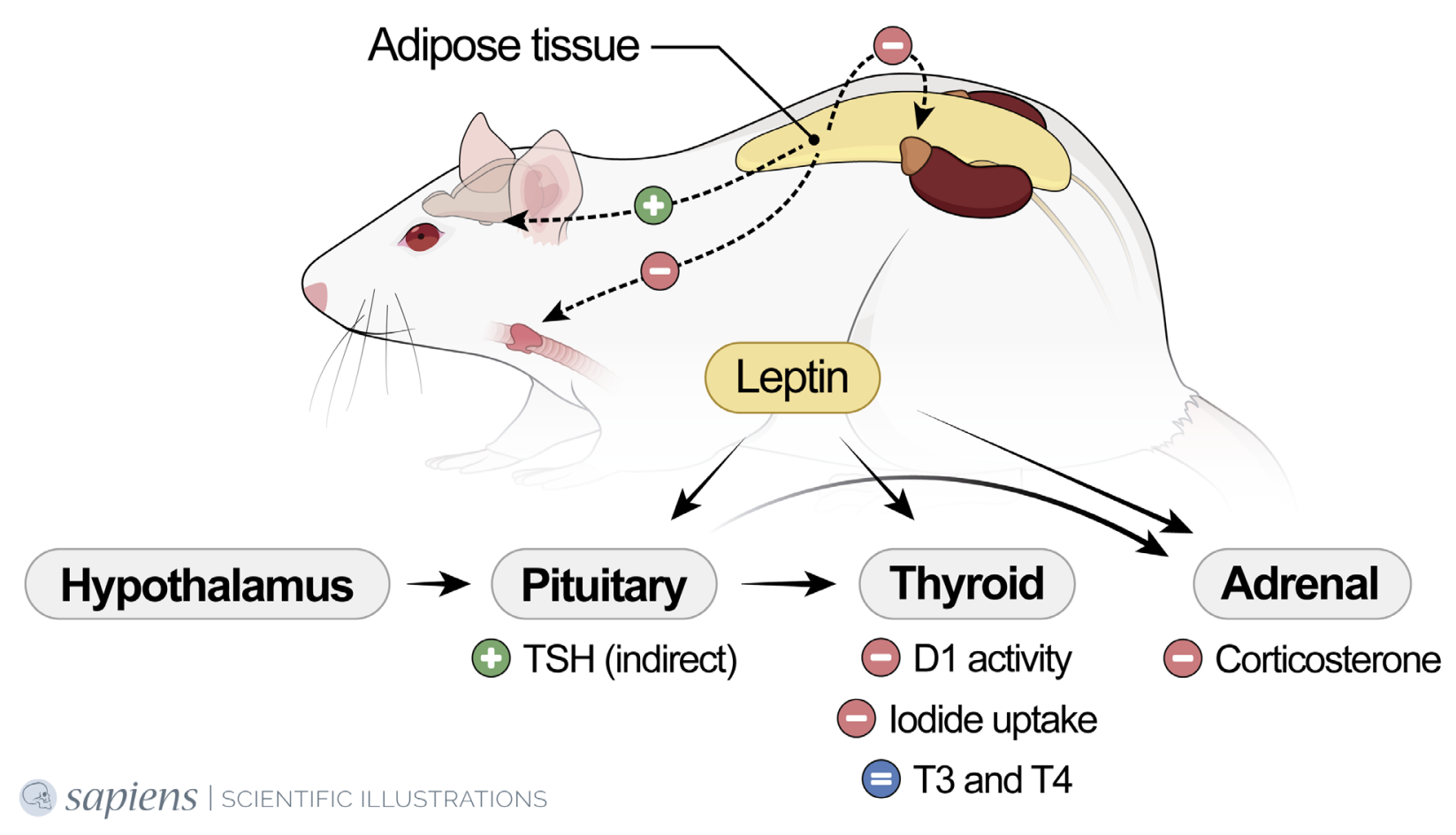

Figure 5. Leptin influences on the hypothalamus-pituitary-thyroid (HPT) axis of rats fed ad libitum. Leptin interacts with its receptor in multiple organs, eliciting direct and indirect effects. Leptin is a known positive regulator of TSH secretion, which might be secondary to its stimulatory effect on hypothalamic TRH. However, hyperleptinemia has repressive effects on thyroid function. Leptin diminishes thyroid iodide uptake and thyroid's deiodinase 1 activity in vivo and in vitro. Thyroid hormones levels do not seem to be modulated in this condition. Hyperleptinemia also exerts important effects on the hypothalamus-pituitary-adrenal gland, as shown by reduced corticosterone levels. 
was supported by grants from Fundação Carlos Chagas Filho de Amparo à Pesquisa do Estado do Rio de Janeiro (FAPERJ), Programa de Núcleos de Excelência (PRONEX), and Conselho Nacional de Desenvolvimento Científico e Tecnológico (CNPq).

\section{REFERENCES}

AHIMA RS, PRABAKARAN D, MANTZOROS C, QU D, LOWELL B, MARATOS-FLIER E \& FLIER JS. 1996. Role of leptin in the neuroendocrine response to fasting. Nature 382: 250-252.

ANNUNZIATO L, DI RENZO GF, SCHETTINI G \& PREZIOSI P. 1977. Increased plasma corticosterone and decreased plasma thyroid-stimulating hormone levels in rats treated with vincristine. Cancer Res 37: 2574-2577.

ARAUJO RL, ANDRADE BM, DA SILVA ML, FERREIRA ACF \& CARVALHO DP. 2009. TisSUe-specific deiodinase regulation during food restriction and low replacement dose of leptin in rats. Am J Physiol Metab 296: E1157-E1163.

ARAUJO RLADE BM, PADRÓN AS, GAIDHU MP, PERRY RLS, CARVALHO DP \& CEDDIA RB. 2010. High-Fat Diet increases thyrotropin and oxygen consumption without altering circulating 3,5,3'-triiodothyronine (T3) and thyroxine in rats: the role of iodothyronine deiodinases, reverse T3 production, and whole-body fat oxidation. Endocrinology 151: 3460-3469.

ARAUJO RL, DE ANDRADE BM, DE FIGUEIREDO ÁSP, DA SILVA ML, MARASSI MP, DOS SANTOS PEREIRA V, BOUSKELA E \& CARVALHO DP. 2008. Low replacement doses of thyroxine during food restriction restores type 1 deiodinase activity in rats and promotes body protein loss. J Endocrinol 198: 119-125.

BARZILAI N, WANG J, MASSILON D, VUGUIN P, HAWKINS M \& ROSSETTI L. 1997. Leptin selectively decreases visceral adiposity and enhances insulin action. J Clin Invest 100: 3105-3110.

BERRY MJ, BANU L \& LARSEN PR. 1991. Type I iodothyronine deiodinase is a selenocysteine-containing enzyme. Nature 349: 438-440.

BLAKE NG, ECKLAND DJA, FOSTER OJF \& LIGHTMAN SL. 1991. Inhibition of hypothalamic thyrotropin-releasing hormone messenger ribonucleic acid during food deprivation. Endocrinology 129: 2714-2718.

BRADFORD MM. 1976. A rapid and sensitive method for the quantitation of microgram quantities of protein utilizing the principle of protein-dye binding. Anal Biochem 72 : 248-254.
CABANELAS A, LISBOA P, MOURA E \& PAZOS-MOURA C. 2007. Acute effects of leptin on 5'-deiodinases are modulated by thyroid state of fed rats. Horm Metab Res 39: 818-822.

CAMPFIELD L, SMITH F, GUISEZ Y, DEVOS R \& BURN P. 1995. Recombinant mouse OB protein: evidence for a peripheral signal linking adiposity and central neural networks. Science 269: 546-549.

CARVALHO DP \& DUPUY C. 2017. Thyroid hormone biosynthesis and release. Mol Cell Endocrinol 458: 6-15.

CETTOUR-ROSE P, BURGER AG, MEIER CA, VISSER TJ \& ROHNERJEANRENAUD F. 2002. Central stimulatory effect of leptin on T3 production is mediated by brown adipose tissue type II deiodinase. Am J Physiol Metab 283: E980-E987.

CHAN JL, HEIST K, DEPAOLI AM, VELDHUIS JD \& MANTZOROS CS. 2003. The role of falling leptin levels in the neuroendocrine and metabolic adaptation to short-term starvation in healthy men. J Clin Invest 111: 1409-1421.

COLEMAN DL. 1978. Obese and diabetes: Two mutant genes causing diabetes-obesity syndromes in mice. Diabetologia 14: 141-148.

CONNORS JM, DEVITO WJ \& HEDGE GA. 1985. Effects of food deprivation on the feedback regulation of the hypothalamic-pituitary-thyroid axis of the rat. Endocrinology 117: 900-906.

COPPOLAA, MELI R \& DIANO S. 2005. Inverse shift in circulating corticosterone and leptin levels elevates hypothalamic deiodinase type 2 in fasted rats. Endocrinology 146: 2827-2833.

DE OLIVEIRA E, TEIXEIRA SILVA FAGUNDES A, TEIXEIRA BONOMO I, CURTY FH, FONSECA PASSOS MC, DE MOURA EG \& LISBOA PC. 2007. Acute and chronic leptin effect upon in vivo and in vitro rat thyroid iodide uptake. Life Sci 81: 1241-1246.

DEEM JD, MUTA K, OGIMOTO K, NELSON JT, VELASCO KR, KAIYALA KJ \& MORTON GJ. 2018. Leptin regulation of core body temperature involves mechanisms independent of the thyroid axis. Am J Physiol Metab 315: E552-E564.

DÖRING H, SCHWARZER K, NUESSLEIN-HILDESHEIM B \& SCHMIDT I. 1998. Leptin selectively increases energy expenditure of food-restricted lean mice. Int J Obes 22: 83-88.

ELMQUIST JK, ELIAS CF \& SAPER CB. 1999. From lesions to leptin: hypothalamic control of food intake and body weight. Neuron 22: 221-232.

FEKETE C, LÉGRÁDI G, MIHÁLY E, HUANG Q-H, TATRO JB, RAND WM, EMERSON CH \& LECHAN RM. 2000. $\alpha$-Melanocyte-Stimulating Hormone is contained in nerve terminals innervating thyrotropin-releasing hormone-synthesizing neurons in the hypothalamic paraventricular nucleus and prevents fasting-induced suppression of prothyrotropin-releasing hormone gene e. J Neurosci 20: 1550-1558. 
FEKETE C, SARKAR S, RAND WM, HARNEY JW, EMERSON CH, BIANCO AC \& LECHAN RM. 2002. Agouti-Related Protein (AGRP) has a central inhibitory action on the hypothalamic-pituitarythyroid (HPT) axis; comparisons between the effect of AGRP and neuropeptide $Y$ on energy homeostasis and the HPT axis. Endocrinology 143: 3846-3853.

FERREIRA ACF, LIMA LP, ARAÚJO RL, MÜLLER G, ROCHA RP, ROSENTHAL D \& CARVALHO DP. 2005. Rapid regulation of thyroid sodium-iodide symporter activity by thyrotrophin and iodine. J Endocrinol 184: 69-76.

FREDERICH RC, LÖLLMANN B, HAMANN A, NAPOLITANO-ROSEN A, KAHN BB, LOWELL BB \& FLIER JS. 1995. Expression of ob mRNA and its encoded protein in rodents. J Clin Invest 96: 1658-1663.

FUSCO A, BERLINGIERI MT, DI FIORE PP, PORTELLA G, GRIECO M \& VECCHIO G. 1987. One- and two-step transformations of rat thyroid epithelial cells by retroviral oncogenes. Mol cell Biol 7: 3365-3370.

GHAMARI-LANGROUDI MV, ELLA KR, SRISAI D, SUGRUE ML, HOLLENBERG AN \& CONE RD. 2010. Regulation of thyrotropin-releasing hormone-expressing neurons in paraventricular nucleus of the hypothalamus by signals of adiposity. Mol Endocrinol 24: 2366-2381.

HALAAS J, GAJIWALA K, MAFFEI M, COHEN S, CHAIT B, RABINOWITZ D, LALLONE R, BURLEY S \& FRIEDMAN J. 1995. Weight-reducing effects of the plasma protein encoded by the obese gene. Science 269: 543-546.

HORVATH TL, DIANO S \& VAN DEN POL AN. 1999. Synaptic interaction between hypocretin (orexin) and neuropeptide $Y$ cells in the rodent and primate hypothalamus: a novel circuit implicated in metabolic and endocrine regulations. J Neurosci 19: 1072-1087.

HWA JJ, FAWZI AB, GRAZIANO MP, GHIBAUDI L, WILLIAMS P, VAN HEEK M, DAVIS H, RUDINSKI M, SYBERTZ E \& STRADER CD. 1997. Leptin increases energy expenditure and selectively promotes fat metabolism in ob/ob mice. Am J Physiol Integr Comp Physiol 272: R1204-R1209.

ISOZAKI O, TSUSHIMA T, NOZOE Y, MIYAKAWA M \& TAKANO K. 2004. Leptin regulation of the thyroids: negative regulation on thyroid hormone levels in euthyroid subjects and inhibitory effects on iodide uptake and $\mathrm{Na}+/$ - symporter mRNA expression in rat FRTL-5 cells. Endocr J 51: 415-423.

IWEN KA, OELKRUG R \& BRABANT G. 2018. Effects of thyroid hormones on thermogenesis and energy partitioning. J Mol Endocrinol 60: R157-R170.

JIN L, ZHANG S, BURGUERA BG, COUCE ME, OSAMURA RY, KULIG E \& LLOYD R V. 2000. Leptin and leptin receptor expression in rat and mouse pituitary cells. Endocrinology 141: 333-339.
KIM MS ET AL. 2000. The central melanocortin system affects the hypothalamo-pituitary thyroid axis and may mediate the effect of leptin. J Clin Invest 105: 1005-1011.

LAWS SC, STOKER TE, FERRELL JM, HOTCHKISS MG \& COOPER RL. 2007. Effects of altered food intake during pubertal development in male and female Wistar rats. Toxicol Sci 100: 194-202.

LÉGRÁDI G, EMERSON CH, AHIMA RS, FLIER JS \& LECHAN RM. 1997. Leptin prevents fasting-induced suppression of prothyrotropin-releasing hormone messenger ribonucleic acid in neurons of the hypothalamic paraventricular nucleus. Endocrinology 138: 2569-2576.

LISBOA PC, CONCEIÇÃO EPS, DE OLIVEIRA E \& MOURA EG. 2015. Postnatal overnutrition programs the thyroid hormone metabolism and function in adulthood. J Endocrinol 226: 219-226.

LISBOA PC, OLIVEIRA KJ, CABANELAS A, ORTIGA-CARVALHO TM \& PAZOS-MOURA CC. 2003. Acute cold exposure, leptin, and somatostatin analog (octreotide) modulate thyroid 5'-deiodinase activity. Am J Physiol Metab 284: E1172-E1176.

MANTZOROS CS ET AL. 2001. Synchronicity of frequently sampled thyrotropin (TSH) and leptin concentrations in healthy adults and leptin-deficient subjects: evidence for possible partial TSH regulation by leptin in humans. J Clin Endocrinol Metab 86: 3284-3291.

MISTRY AM, SWICK AG \& ROMSOS DR. 1997. Leptin rapidly lowers food intake and elevates metabolic rates in lean and ob/ob mice. J Nutr 127: 2065-2072.

NILLNI EA, VASLET C, HARRIS M, HOLLENBERG A, BJØRBAEK C \& FLIER JS. 2000. Leptin regulates prothyrotropin-releasing hormone biosynthesis. J Biol Chem 275: 36124-36133.

NOWAK K, KACZMAREK P, MACKOWIAK P, ZIOLKOWSKA A, ALBERTIN G, GINDA W, TREJTER M, NUSSDORFER G \& MALENDOWICZ L. 2002. Rat thyroid gland expresses the long form of leptin receptors, and leptin stimulates the function of the gland in euthyroid non-fasted animals. Int J Mol Med 9: 31-34.

ORTIGA-CARVALHO T, OLIVEIRA K, SOARES B \& PAZOS-MOURA C. 2002. The role of leptin in the regulation of TSH secretion in the fed state: in vivo and in vitro studies. J Endocrinol 174: $121-125$.

PAMENTER RW \& HEDGE GA. 1980. Inhibition of thyrotropin secretion by physiological levels of corticosterone. Endocrinology 106: 162-166.

PELLEYMOUNTER M, CULLEN M, BAKER M, HECHT R, WINTERS D, BOONE T \& COLLINS F. 1995. Effects of the obese gene product on body weight regulation in ob/ob mice. Science 269: 540-543. 
PERELLO M, ÇAKIR I, CYR NE, ROMERO A, STUART RC, CHIAPPINI F, HOLLENBERG AN \& NILLNI EA. 2010. Maintenance of the thyroid axis during diet-induced obesity in rodents is controlled at the central level. Am J Physiol Metab 299: E976-E989.

RONDEEL JMM, HEIDE R, DE GREEF WJ, VAN TOOR H, VAN HAASTEREN GAC, KLOOTWIJK W \& VISSER TJ. 1992. Effect of starvation and subsequent refeeding on thyroid function and release of hypothalamic thyrotropin-releasing hormone. Neuroendocrinology 56: 348-353.

SAMUELS MH. 1994. Effects of hydrocortisone on pulsatile pituitary glycoprotein secretion. J Clin Endocrinol Metab 78: 211-215.

SAMUELS MH. 2000. Effects of variations in physiological cortisol levels on thyrotropin secretion in subjects with adrenal insufficiency: a clinical research center study. J Clin Endocrinol Metab 85: 1388-1393.

SANCHEZ VC, GOLDSTEIN J, STUART RC, HOVANESIAN V, HUO L, MUNZBERG H, FRIEDMAN TC, BJORBAEK C \& NILLNI EA. 2004. Regulation of hypothalamic prohormone convertases 1 and 2 and effects on processing of prothyrotropinreleasing hormone. J Clin Invest 114: 357-369.

SCARPACE PJ, MATHENY M, POLLOCK BH \& TUMER N. 1997. Leptin increases uncoupling protein expression and energy expenditure. Am J Physiol Metab 273: E226-E230.

SCHWARTZ MW, SEELEY RJ, CAMPFIELD LA, BURN P \& BASKIN DG. 1996. Identification of targets of leptin action in rat hypothalamus. J Clin Invest 98: 1101-1106.

SCHWARTZ MW, SEELEY RJ, WOODS SC, WEIGLE DS, CAMPFIELD LA, BURN P \& BASKIN DG. 1997. Leptin increases hypothalamic pro-opiomelanocortin mRNA expression in the rostral arcuate nucleus. Diabetes 46: 2119-2123.

SCHWARTZ MW, WOODS SC, PORTE D, SEELEY RJ \& BASKIN DG. 2000. Central nervous system control of food intake. Nature 404: 661-671.

SOUZA ECL, DE PADRÓN AS, BRAGA WMO, ANDRADE BM, DE VAISMAN M, NASCIUTTI LE, FERREIRA ACF \& DE CARVALHO DP. 2010. MTOR downregulates iodide uptake in thyrocytes. J Endocrinol 206: 113-120.

STEINBERG GR, BONEN A \& DYCK DJ. 2002. Fatty acid oxidation and triacylglycerol hydrolysis are enhanced after chronic leptin treatment in rats. Am J Physiol Metab 282: E593-E600.

WILBER JF \& UTIGER RD. 1969. The effect of glucocorticoids on thyrotropin secretion. J Clin Invest 48: 2096-2103.

YADAV VK ET AL. 2009. Leptin regulation of bone mass, appetite and energy expenditure relies on its ability to inhibit serotonin synthesis in the brainstem. Cell 138: 976-989.
ZHANG Y, PROENCA R, MAFFEI M, BARONE M, LEOPOLD L \& FRIEDMAN JM. 1994. Positional cloning of the mouse obese gene and its human homologue. Nature 372: 425-432.

\section{How to cite}

HECHT F, CAZARIN J, ROSSETTI CL, ROSENTHAL D, ARAUJO RL \& CARVALHO DP. 2021. Leptin negatively regulates thyroid function of Wistar rats. An Acad Bras Cienc 93: e20201551. DOI 10.1590/0001-3765202120201551.

Manuscript received on October 5, 2020;

accepted for publication on November 24, 2020

\section{FABIO HECHT*}

https://orcid.org'0000-0001-9110-2587

\section{JULIANA CAZARIN*}

https://orcid.org/0000-0002-5728-1857

\section{CAMILA L. ROSSETTI}

https://orcid.org/0000-0002-0513-9963

\section{DORIS ROSENTHAL}

https://orcid.org'0000-0001-7136-5961

\section{RENATA L. ARAUJO}

https://orcid.org/0000-0002-1554-2908

\section{DENISE P. CARVALHO}

https://orcid.org/0000-0001-6933-6424

Universidade Federal do Rio de Janeiro, Instituto de Biofísica Carlos Chagas Filho, Laboratório de Fisiologia Endócrina Doris Rosenthal, Av. Carlos Chagas Filho, 373, 21941-902 Rio de Janeiro, RJ, Brazil

Correspondence to: Denise Pires de Carvalho

E-mail:dencarv@biof.ufrj.br

*contributed equally to this work

\section{Author contributions}

F.H., J.C., R.L.A, and D.P.C. conceived and designed the experiments, F.H., J.C., and R.L.A performed the experiments, F.H. and J.C. analyzed the data, and F.H, J.C., C.L.R., D.R., and D.P.C wrote the paper.

\section{(cc) BY}

